UDK 821.111(540)-3-055.2.09”195/199”

\title{
THE DEVELOPMENT OF INDIAN ENGLISH POST-COLONIAL WOMEN'S PROSE
}

\author{
Tina Grobin
}

\begin{abstract}
Indian English post-colonial women's prose has seen many a change in the last sixty years since the pioneering writers gave voice to the Indian women. By breaking away from the burden of the colonial past and the traditional limitations of Indian society, the writers carved out a place for a distinct female identity in the Indian English literary sphere. The more recent women's prose addresses a wide range of universal issues of human experience, usually closely interwoven with the colourful heritage of the Indian subcontinent. As such it has become a highly acclaimed and internationally recognized global voice of contemporary India and the Indian diaspora.
\end{abstract}

Key words: post-colonial literature, Indian English women's prose, the treatment of subject matter

The spread of the European colonial hegemony over the territories of Africa, South Asia, Australia, New Zealand, the Caribbean and elsewhere had a major impact on the political, economic and cultural structure of the contemporary societies. In fact, colonialism influenced "more than three-quarters of the people living in the world today" (Ashcroft and Griffiths and Tiffin, 1). The second half of the twentieth century saw the subjugated nations wage an uphill battle of claiming back their essence and re-establishing their broken identities in the context of the newly gained independence from colonial empires. The legacy of colonial rule became the subject of research of the post-colonial theory. The main preoccupations of postcolonialism are therefore the influences of imperial hegemony on the indigenous population, the process of decolonization and its consequences, the issues of identity and the language(s) and the reestablishment of the social and political roles in the framework of globalization or, according to Boehmer, "restorative history" (Boehmer 186). Post-colonial literary production played an important role in the process of national rebuilding since it enabled people to make their voice heard. The following paragraphs discuss the development of the Indian English post-colonial women's prose, with the intention to highlight its role and importance in the process of defining women's social, historical and political roles in modern India. 
The term Indian English post-colonial literature includes literary achievements of Indian authors in the homeland who write in English, and the literary voices of the Indian diaspora. The beginnings of Indian literary creativity in English date back to the period of the British imperial subjugation of the continent. It was especially the novel that achieved prominence and recognition with the emergence of authors Mulk Raj Anand, Raja Rao and R. K. Narayan who, at the turn of the twentieth century, set out on the literary path paved by their predecessor, a poet, philosopher and novelist Rabindranath Tagore. The socio-political changes brought about by the independence in 1947 resulted in the rise of women writers who could, empowered by a hint of approaching changes of attitudes towards the traditional role of Indian women, finally give voice to their illustration of the Indian experience. The authors to break new ground were Kamala Markandaya, Nayantara Sahgal, Ruth Prawer Jhabvala and Anita Desai. They were followed by Shashi Deshpande, Manju Kapur, and the representatives of the Indian diaspora Bharati Mukherjee and Chitra Banerjee Divakaruni. By addressing a number of topical issues and by perfecting the style of literary expression, they laid the ground for the prominent contemporary representatives of the Indian English literature, including Arundhati Roy, Anita Nair, Kiran Desai, Githa Hariharan and Jhumpa Lahiri, who can finally compete on equal terms with their male counterparts, for instance Salman Rushdie, Amit Chaudhuri, Vikas Swarup and Vikram Chandra.

To understand the true nature of Indian English women's literature, it is deemed essential to draw on some historical background, with respect to the specific social status of women in India. Shriwadkar points out that the roots of gender issues date back to the period as early as the ancient Hindu civilization where the gap between men and women could already be traced in literature. To support her claim, the author argues that the infamous Hindu epic poem Ramayana, which defined the ideal image of a woman as a quiet, loyal, virtuous, pure and suffering servant, whose role was to satisfy the needs of a man (embodied in the role of Rama, the protagonist, portrayed as the epitome of virtue) and her family, undoubtedly promoted the idea of female submissiveness and sacrifice, which was further developed by other myths and legends that had an important teaching role in ancient India (Shriwadkar 49). The archetype of the ideal woman and her prescribed roles of a daughter, wife and mother became deeply rooted in cultural tradition, and it soon became established as a social norm that the woman's main role was to serve her husband and raise (preferably male) children, or as Bumiller puts it, "be the mother of a hundred sons" (Bumiller 10). This gave rise to double standards in treating men and women and led to gender discrimination. In the society organised on gender principles women became perceived as the "other" sex, the term later used by Simone de Beauvoir in reference to women's inequality. Given the challenging social position of women, it is not surprising that the predominant theme of the women's prose is the Indian woman in relation to the patriarchal, tradition-bound society and the struggle to overcome its constraints. In the aftermath of the uncertain post-independence period the early prose focused on issues such as economic hardship, poverty and the clash between the rural and the urban middle-class society, addressed the concerns of the emerging post-colonial generation in relation to the burden of the British legacy and captured the suffering and sacrifice of the downtrodden Indian women, to name a few of the recurring topics of Kamala Markandaya, Nayantara Sahgal and Ruth Prawer 
Jhabvala's novels. Despite the relative simplicity of the vocabulary and the narrative, the early literary production represented a breakthrough in the further development of the women's writing and it offered a valuable insight into the reality of Indian women of that time.

As a result of the country witnessing a rapid development in the field of sociopolitical, economic and cultural contexts, the women's writing began to break with tradition. Globalisation and the increased exposure to intercultural dialogue brought about changes in the existing social structures, challenged the traditional concepts, values and the way of life, and finally began to question the untouchable issue of gender roles. It became possible to start redefining the social position of women and the impact of social changes reflected in literature. Empowered by the transforming social environment, women writers began to break away from the British culture and the traditional social limits in order to establish a distinct identity of their own, which resulted in the emergence of new themes and fresh approaches to their application. In the light of transforming the traditional women's roles, one of the central motifs of the women's writing of the late sixties, the seventies and the eighties became the clash of traditional and modern values, which ultimately led to an identity crisis of the protagonists. As Seshadri points out, the Indian woman now finds herself in the position where she experiences the need to claim an individual identity but is limited by the remaining restrictions of her social position imposed on women by the traditional society (Seshadri 49). It should be observed at this point that the changes in the attitudes towards women took effect rather slowly and in the beginning they addressed a limited part of the society (i.e. the educated upper classes). The author explains that the primary concern of the protagonist is her personal conflict "between her will to disinherit the dominant tradition and her resistance to do so" (49) as the protagonist is still heavily influenced by the traditional norms and other social boundaries. In order to resolve the personal conflict that stands in the way of her liberation, the protagonist is sent on a quest of self-discovery and reclaiming selfhood. According to Seshadri, the process of establishing an individual identity denotes tackling the inner conflict of the "divided loyalties" (154) and dealing with the discouraging and often hostile social environment at the same time. Let us now look at how the authors carved out the space for the female identity.

To begin with, the protagonist who set out on the identity quest in order to deal with her personal conflict was equipped with the ability of a psychoanalytic insight, which enabled the psychological development of the fictional character. One of the first multi-layered protagonists to step on the path of self-searching was Anita Desai's Maya in Cry, the Peacock. The theme of the personal conflict enabled Desai and other contemporaries to relate their protagonists to the universal issues of experiencing loneliness, isolation, fear, doubt and guilt, which resulted in the authenticity of the protagonists. What is more, the conflict forced the protagonist to embark on a spiritual quest in order to break free from the limitations of the tradition, recognize her true identity and make way for expressing it. The means that the writers employed to liberate the protagonists was the element of mobility and personal growth. The protagonists had to abandon their roles within their families and their immediate environment in order to break with the old patterns of behaviour and venture beyond the recognized social norms and traditions, often by leaving their life behind, and, more importantly, they had to achieve a higher 
level in the process of personal growth. The extent to which the protagonists were successful in walking the path of upward mobility and personal growth, however, remains a subject of great variety.

Rama Mehta's protagonist of the 1977 novel Inside the Haveli, for instance, embodies one of the lowest degrees of female mobility. The protagonist is introduced as a fairly open-minded urban girl who is married off in the traditional environment of rural Rajasthan where she is entrapped by the restrictions of the institution of orthodox purdah, denied social contacts, personal freedom and is reduced to a role of a silenced and defeated wife and mother. Mehta symbolically strengthens the element of female immobility through the protagonist's regression from a fairy independent to a totally submissive role and with the final act of the protagonist succumbing to the pressure of the tradition and embracing her destiny to remain repressed, passing on the message to the next generations of women. Vrinda Nabar, who has published widely on post-colonial and women's issues, argues that Mehta should have questioned the institution of purdah instead of glorifying it (Nabar 41). As such, Mehta's novel was a painful reminder that the inferiority of women was still an issue deeply rooted in Indian psyche and far from being resolved.

On the other hand, writers generally strived to move the social boundaries and they portrayed the protagonists who demanded independence and a voice of their own. Manju Kapur created two powerful protagonists, Astha in A Married Woman (2003) and Virmati in Difficult Daughters (1988) that challenged the conventional social norms by insisting on pursuing artistic and academic careers, taking part in the political sphere, traditionally the domain of men, and defying the traditional role of a wife by violating the sanctity of marriage with getting involved in a lesbian relationship (Astha) and eloping with a married man (Virmati). The non-conformity of Kapur's protagonists facilitated their upward mobility on the identity scale and enabled them to uphold the remote idea of individual freedom. However, they failed to realize their full potential, despite the fact that they stepped in places female protagonists had not ventured before. Astha lacked the strength to carry on with the indicated path of emancipation and returned to, as summarized by her husband, "what [she] know[s] best, the home, children, teaching" (116), and Virmati failed, too. Kapur hinted at the possibility of expanding the female space with the third generation of her women characters in Difficult Daughters. Namely, the last chapter ends with the story of Virmati's daughter Ida, who decides to set out in on a path of self-discovery and personal growth after a failed marriage.

Yet a higher level of female mobility is achieved by the protagonist of Anita Desai's novel Where Shall We Go This Summer (1982). Sita is depicted as a dissatisfied, middle aged pregnant mother and wife who leaves her husband and two children and moves to the island where she had spent her childhood in order to put together the broken fragments of her identity. The physical retreat from her marriage enables the protagonist to make more space for her individuality and establish communication with her inner self in order to be able to recognize her own needs. In fact, the motif of communication is presented as the central element which develops throughout the narrative and facilitates the protagonist's personal growth. At first Sita voices her dissatisfaction and demands change by abandoning her family, a way of a silent protest, but gradually she learns to communicate and make her voice heard, which is the ultimate level reached on the path 
of her self-development. After a thorough self-searching, Sita comes to terms with her past and accepts her role within the society deciding that her place is with the family. Seshadri explains that Sita emerges from her personal conflict as a winner because the fact that she chose to rebel made it legitimate to make peace with her fate and embrace her old life with alterations as the only suitable choice for her (Seshadri 91). Despite the fact that Sita's journey is cyclic, she manages to secure some changes to her life. Nevertheless, the bitter taste of settling for the compromise instead of choosing complete freedom persists.

Another writer to demand change in the social position of women is Shashi Deshpande. Deshpande is one among a few internationally acclaimed women authors who remain based in the homeland. On her three decades long literary path, she has strived to give women the voice to stand up for themselves and empower them to claim independence and equality. She says that her role is to promote women's writing and advance its equal representation and evaluation in the literary mainstream where it still remains looked down upon by some critics who, according to Deshpande, still have not "learnt to deal with writing by women as just writing, whether it's good or bad". ${ }^{1}$ Her novels portray protagonists who dare to step on the path of liberation but are usually impeded by the hostile social environment and their personal inhibitions to break with the tradition. In the end, the protagonist emerges from her personal conflict stronger, she moved upwards in terms of individual freedom and she is geared up for her newly defined life, however still within the accepted social limits. There are no happy endings with Deshpande but the reader feels the boundaries of women's freedom have been moved forward and are going to be dealt with further in the future.

The Dark Holds No Terrors (1980) introduces a highly mobile, educated and financially independent protagonist who is trapped in a vicious circle of having to justify and defend her freedom against the traditional society. Sarita's mission is to redefine her broken identity which is a result of a dissatisfying marriage to a physically and mentally abusive husband as well as a consequence of her constant inner battles with guilt and the feelings of insufficiency caused by the expectations of the environment. As an educated woman and the family breadwinner, she experiences a lot of pressure from the patriarchal society. Despite creating a protagonist who develops to the point of being equal to a man in all respects, Deshpande illustrates how Sarita completely loses her own identity in the process of proving herself, becoming terrified of "not existing. No, worse. Of being just a ventriloquist's dummy, that smiles, laughs, and talks only because of the ventriloquist" (22). In order to face her inner battle, she isolates herself from her husband and children by moving back to her parents' home where she seeks the answers about the meaningfulness of her existence and tries to find the path back to herself.

According to Seshadri, Sarita is the first protagonist "to move in places untrodden by fictional heroines" (Seshadri 103). Not only does Deshpande provide an utterly powerful and highly independent protagonist, she also takes the issue of a personal conflict from the individual to the collective level. Namely, through the symbolism employed in the roles of the male characters, the violent and abusive husband and the

\footnotetext{
${ }^{1}$ De, Aditi. (2003, 28 August). Breaking that Long Silence. The Hindu. Retrieved from http://www. hinduonnet.com
} 
passive and impotent father, the author points the finger at the (patriarchal) society which does not allow women to express themselves or develop their potential and is incapable of providing support. The conflicts on the individual and collective levels are finally resolved through the powerful element of communication. The key to Sarita's redemption is to establish a monologue with herself to recognize her needs, and a dialogue with her environment to find the way to communicate her needs to her surroundings. By realizing that she has the power to be responsible for her life, Sarita can redefine her identity and embrace her new self. This achieved, the final chapter disappoints in lacking the determination to clearly signal the beginning of a new life for Sarita. As Surendran points out, the protagonist's fulfilment is never definite but is rendered only as a possibility at the end of the novel (Surendran 112).

Another milestone in women's prose was the publication of Arundhati Roy's debut novel The God of Small Things in 1997. In terms of defining female identity, Roy creates highly mobile and independent female characters, perhaps the most accomplished fictional characters in that respect so far. What is more, Roy subtly sets the recurrent theme of the Indian woman and the society against other topical issues of the Indian as well as global community. Similarly to Desai, Deshpande and Kapur, who treat the theme of female identity within a cultural, historical and political setting, ranging from the partition of India (Desai's Clear Light of Day, Kapur's Difficult Daughters), Hindu-Muslim conflicts (Kapur's A Married Woman, Deshpande's That Long Silence) to the clash between the Eastern and Western cultures (Desai's Fasting, Feasting), Roy questions issues such as the institution of caste, gender bias, social discrimination, class conflicts, Indian history, culture and politics, corruption, (physical and mental) violence, sexual abuse and incest. The plot revolves around the lives of Ammu and her twins and it shifts back and forth from 1969 to 1993. Ammu is depicted as a rebellious daughter of a violent father and a long-suffering mother, who seeks refuge in an unhappy marriage to an abusive alcoholic whom she divorces and later initiates a relationship with a member of the lowest caste, the Untouchables. The fate of Ammu, her children and her lover within Roy's biased and immoral society is determined by 'small things' as suggested in the title itself. It is the human fears, prejudice, malice, immorality and injustice that destroy the lives of Ammu, who dies at thirty-one years of age because of poverty, her lover Velutha, who becomes a scapegoat and is brutally murdered by the police on the basis of false allegations, her son Estha, who goes numb as a consequence of abuse, guilt and the stress of separation from his family, and her daughter Rahel, who returns to India after a failed marriage in the USA and tries to scrape together the lives of herself and her twin brother Estha. The novel reads like a pessimistic illustration of a contemporary society which is ridden with injustice and human suffering. Or as Nishant puts it, " $[\mathrm{w}]$ ishing for one day, a single moment, that is free from suffering, boundaries and prejudice to last for a lifetime is a dream inverted and ultimately defeated in Arundhati Roy's first novel The God of Small Things". ${ }^{2}$ As such, the novel is easily related to and along with Roy's rich language and a unique narrating technique, the treatment of universal themes of human existence set within the Indian context enables the novel to address a wide international readership, a trend that is starting to prevail in the field of

\footnotetext{
${ }^{2}$ Nishant, Shulin. (2001, 4 June). Arundhati Roy's The God of Small Things. Postcolonialweb.org. Retrieved from http://www.scholars.nus.edu.sg
} 
most recent contemporary Indian English women's prose with authors such as Jhumpa Lahiri, Anita Nair, Kiran Desai and many other prolific representatives of the Indian literary voice. The open ending of Roy's novel signals the idea that the future may have the answers to the burning questions women have been addressing through literature. It is now in the hands of the new generation of writers to carry the women's voice further afield, a mission they definitely seem to be well suited to accomplishing.

\section{CONCLUSION}

Indian English post-colonial women writers Arundhati Roy, Githa Hariharan, Shashi Deshpande, Anita Desai, Manju Kapur, Anita Nair and the voices of Indian diaspora Jhumpa Lahiri, Bharati Mukherjee, Chitra Banerjee Divakaruni, and most recently Kiran Desai, the daughter of Anita, have managed to carve out their spaces next to the prominent male writers of the contemporary post-colonial Indian English literary canon, including Salman Rushdie, Amitav Ghosh, Vikram Seth, Rohinton Mistry, Amit Chaudhauri, Shashi Tharoor, Vikram Chandra, and others. The paper examines the process that the women's prose underwent in order to become the voice of the contemporary Indian experience. Given the specific social situation of women in India, the predominant theme of the women's prose is the illustration of the Indian woman in relation to the (hostile) society. The early variations on the theme portrayed the hardships of a struggling Indian female within the patriarchal, tradition-bound society, set in the wider context of the emerging post-colonial India trying to come to terms with its turbulent past. Despite the occasional stylistic weaknesses, the early novels provided an important insight in the lives of Indian women around the time of India's independence. Against a backdrop of rapid social changes the recurring theme was further developed by writers addressing a number of topical issues concerning women and their role in the society. They questioned the existing social norms and they pushed back the boundaries of the traditional role of women by giving their protagonists a sense of personal identity and a voice of their own. The central element of defining the women's role was skilfully interwoven with other relevant themes of the Indian reality, such as family relations, religious tensions, history, culture, politics and social discrimination, which gave credibility to women's writing and created literary space for women's voices. The writers empowered women, granted them identity, mobility and the freedom of expression which they had been denied before. For this reason, the late twentieth century women's literature made a significant contribution to the change of attitudes towards the position of women in the Indian society and literature, and as such it holds an important place in the development of women's writing. The issue of the status of Indian women remains controversial even at the turn of the twenty-first century and it continues to serve as a recurrent motif of the most recent women's fiction, however, it is employed alongside a wide range of globally related themes introduced by writers in order to account for the phenomena of the modern society. Arundhati Roy's The God of Small Things, for instance, addresses a set of universal issues of human experience. Roy tackles the questions of caste, race, gender inequality, (sexual, mental and physical) abuse, corruption and (domestic) violence within a socially and politi- 
cally in-depth framework, and she does it with a powerful poignancy that the earlier prose by women but seldom witnessed. Furthermore, Kiran Desai ventures even further afield with her novels The Inheritance of Loss and Hullabaloo in the Guava Orchard to explore the complex problems of globalism, class, the divide between the rich and the poor, racial questions, immigration issues, alienation and loneliness, which are skilfully knitted in the multi-layered narrative, whereas Jhumpa Lahiri's Unaccustomed Earth, The Namesake and Interpreter of Maladies address the present-day multicultural society and its predicaments, such as the clash of cultures, the generation gap and the theme of identity in the light of the immigration context. Finally, contemporary prose by women has excelled in the field of literary style, employing rich, eloquent language and colourful, detailed narrative. The novels convey strong emotion and provide a penetrating, deeply intimate insight into the most acute concerns of the present-day society. The acuity, depth and sincere originality have won Indian women writers praise and great international acclaim. In a nutshell, Indian women writers have succeeded in raising their voices over the last six decades and have heralded an era of equal opportunities with a bright future ahead of them.

Ljubljana, Slovenia

\section{WORKS CITED}

Ashcroft, Bill, Gareth Griffiths and Helen Tiffin. The Empire Writes Back: Theory and Practice in Post-colonial Literatures. London and New York: Routhledge, 1989.

Boehmer, Elleke. Colonial and Postcolonial Literature: Migrant Metaphors. Oxford and New York: Oxford UP, 1995.

Bumiller, Elisabeth. May You Be the Mother of a Hundred Sons. New Delhi: Penguin Books India, 1991.

Desai, Anita. Where Shall We Go This Summer. New Delhi: Orient Paperbacks, 2005.

Cry, the Peacock. New Delhi: Orient Paperbacks, 2005.

. Clear Light of Day. London: Vintage, 2001.

. Fasting, Feasting. London: Chatto \& Windus, 1999.

Desai, Kiran. The Inheritance of Loss. New York: Grove Press, 2006.

. Hullabaloo in the Guava Orchard. London: Faber and Faber, 1999.

Deshpande, Shashi. The Dark Holds No Terrors. New Delhi: Penguin Books India, 1990.

Kapur, Manju. Difficult Daughters. New Delhi: Penguin Books India, 1989.

. A Married Woman. London: Faber and Faber, 2003.

Lahiri, Jhumpa. Interpreter of Maladies. London: Flamingo, 2000.

. The Namesake. London: Harper Perennial, 2004.

. Unaccustomed Earth. London: Bloomsbury Publishing, 2009.

Markandaya, Kamala. Nectar in a Sieve. New York: John Day, 1954.

Mehta, Rama. Inside the Haveli. New Delhi: Penguin Books India, 1996.

Nabar, Vrinda. Caste As Woman. New Delhi: Penguin Books India, 1995.

Nair, Anita. Ladies Coupé. London: Vintage, 2003.

Roy, Arundhati. The God of Small Things. New Delhi: Penguin Books India, 2002.

Shirwadkar, Meena. Image of Woman in the Indo-Anglian Novel, New Delhi: Sterling, 1979.

Seshadri, Vijayalakshmi. The New Woman in Indian-English Women Writers Since the 1970s. Delhi: B.R. Publishing Corporation, 1995.

Surendran, K.V. Women's Writing in India: New Perspectives. New Delhi: Sarup and Sons, 2002. 
Online Sources:

De, Aditi. (2003, 28 August). Breaking that Long Silence. The Hindu. Retrieved from http://www. hinduonnet.com

Nishant, Shulin. (2001, 4 June). Arundhati Roy's The God of Small Things. Postcolonialweb.org. Retrieved from http://www.scholars.nus.edu.sg 